\title{
Intracellular Transport of Viruses and Their Components: Utilizing the Cytoskeleton and Membrane Highways
}

\author{
Phillip A. Harries, ${ }^{1}$ James E. Schoelz, ${ }^{2}$ and Richard S. Nelson ${ }^{3}$ \\ ${ }^{1}$ Department of Biology, Pittsburg State University, Pittsburg, KS 66762, U.S.A.; ${ }^{2}$ Department of Plant Sciences, University \\ of Missouri, Columbia 65211, U.S.A.; ${ }^{3}$ Plant Biology Division, Samuel Roberts Noble Foundation, Inc., Ardmore, OK 73401, \\ U.S.A.
}

Submitted 21 May 2010. Accepted 8 July 2010.

\begin{abstract}
Plant viruses are obligate organisms that require host components for movement within and between cells. A mechanistic understanding of virus movement will allow the identification of new methods to control virus systemic spread and serve as a model system for understanding host macromolecule intra- and intercellular transport. Recent studies have moved beyond the identification of virus proteins involved in virus movement and their effect on plasmodesmal size exclusion limits to the analysis of their interactions with host components to allow movement within and between cells. It is clear that individual virus proteins and replication complexes associate with and, in some cases, traffic along the host cytoskeleton and membranes. Here, we review these recent findings, highlighting the diverse associations observed between these components and their trafficking capacity. Plant viruses operate individually, sometimes within virus species, to utilize unique interactions between their proteins or complexes and individual host cytoskeletal or membrane elements over time or space for their movement. However, there is not sufficient information for any plant virus to create a complete model of its intracellular movement; thus, more research is needed to achieve that goal.
\end{abstract}

A critical aspect of a systemic infection of a plant by a virus is the ability of the virus to move within and between cells. Movement requires host factors reflecting the obligate nature of viruses. Without the ability to move, a virus infection would be limited to the initially infected cell and systemic disease would not occur. An understanding of virus movement is important not only to understand the virus infection process and identify novel methods to limit virus-induced systemic disease symptoms but also to gain a keener insight into general host intra- and intercellular transport pathways responsible for normal cellular function.

Although it is conceivable that the intracellular movement of viruses could occur via controlled diffusion through the cytoplasm, the bulk of plant and animal virus movement research has focused on the host cytoskeleton and membrane systems because these cellular components are known to play key roles in the transport of vesicles, organelles, and macromolecules within cells. In the case of animal viruses, it has been shown that both the microtubule and actin cytoskeletons participate in active transport at multiple steps of the infection cycle, including binding of virions to receptors, internalization, movement

Corresponding author: R. S. Nelson; E-mail: rsnelson@noble.org to the nucleus, genome replication, virion assembly, and virus egress (Greber and Way 2006; Pollard and Cooper 2009; Radtke et al. 2006). The association of animal viruses with membranes has long been linked to virus replication and, more recently, to movement (Burckhardt and Greber 2009; Pierini et al. 2009).

Both microtubules and actin filaments (microfilaments) are composed of small subunits (tubulin dimers and actin monomers, respectively). These subunits can rapidly polymerize or depolymerize, resulting in a very dynamic and constantly changing cytoskeleton. In fact, cytoskeletal dynamics may provide the force necessary to move cellular components or viruses within and between cells (Burckhardt and Greber 2009). Alternatively, microtubules and microfilaments may serve as tracks for their respective motor proteins (dynein/dynactin and kinesin for microtubules and myosins for microfilaments) to traffic cargo. Although both types of microtubule motors have been implicated in the intracellular movement of many different animal viruses (Greber and Way 2006; Radtke et al. 2006), the study of the role of myosin motors in animal virus movement remains in its infancy (Forest et al. 2005; Sasaki et al. 1995). In plants, myosins are a large superfamily with all members falling into two classes (class VIII and class XI). Each plant myosin consists of a conserved head domain that binds to microfilaments and a divergent tail domain that can bind to distinct cargo (Lee and Liu 2004; Li and Nebenführ 2007). Only within the last few years has the importance of myosins for plant virus intra- and intercellular movement been investigated.

Plant and animal membranes are composed of lipids, carbohydrates, and proteins whose composition changes according to the membrane type, the time of analysis, and the environment in which the membrane resides. Membranes serve as a transport system for proteins synthesized on the endoplasmic reticulum (ER), exiting the ER after proper folding to the Golgi complex in coat or complex II (COP II)-like vesicles in the absence of cytoskeleton involvement (Moreau et al. 2007). Transport to other membranes can occur from the Golgi complex or directly from the ER (Hanton et al. 2007; Moreau et al. 2007). Proteins and other membrane components are returned to the ER through endocytosis from Golgi via COP I vesicles or from other membranes (Ellgaard and Helenius 2003). For plant cells, the ER and plasma membrane (PM) have the additional and important role of providing membrane continuity through plasmodesmata (PD) that connect most plant cells. PD are "tunnels" which regulate traffic between cells and include both a cytoplasmic channel and the ER (Maule 2008). Thus, the PM and ER are continuous between cells, providing structures for virus products to associate with as they travel in the symplasm that connects cells. Proteins 
may associate with membranes as integral membrane proteins, anchored to the membrane through a host protein, or indirectly through an association with the cytoskeletal network. Transport along a membrane within or between cells may occur by cytoskeletal-mediated movement of a section of the membrane or regulated movement within the membrane. Within membranes, receptors such as the soluble $N$-ethylmaleimide-sensitive factor adaptor protein receptor (SNARE) serve as signal and target receptors for membrane fusion events (Lipka et al. 2007; Moreau et al. 2007). Plant and animal virus proteins associate with multiple membrane components during their life cycle, including the ER, Golgi, vacuolar, peroxisomal, chloroplastic, mitochondrial, and endosomal vesicle membranes (Hwang et al. 2008; Netherton et al. 2007; Sanfaçon 2005).

Plant membranes were not included in some early models describing plant virus intra- and intercellular movement. One reason for this is that, although membranes have long been known to be important for plant virus translation and replication, it is difficult to separate those activities from others required for virus movement. Even now, there is only a small subset of viral proteins that interact with membranes which are known to directly influence virus movement. The situation is further complicated by the possibility that virus accumulation, including translation and replication, and movement are linked activities. Clearly, our ability to separate the virus accumulation and movement functions of plant membranes will dramatically affect our understanding of virus movement.

Although there are undoubtedly a number of similarities between the movement of animal and plant viruses, certain cellular differences, particularly the presence of intercellular connections in the form of PD, have likely driven the evolution of distinct movement strategies by viruses in plants. As in animal studies, the bulk of the early plant virus movement work focused on the role of microtubules in virus movement. Work on microtubules continues and additional studies have demonstrated the involvement of microfilaments in the movement process of certain plant viruses. Given the close association between microfilaments and ER and the presence of some viral proteins associated with movement in membranes, it is not surprising that a role for the plant endomembrane system has also been proposed for the movement of some plant viruses. This review will examine the influence of microtubules, microfilaments, and membranes on plant virus intracellular movement and, when relevant, the influence of this activity on intercellular virus movement. It will further highlight differences in the movement processes of different viruses and their components. It generally will not review virus protein interactions with the host membranes at the PD or the effects of suppression of silencing on movement (BenitezAlfonso et al. 2010). The reader should also understand that this article does not review the influence of the cytoskeleton and membranes on virus systemic movement, an activity separate but dependent on virus intracellular and intercellular movement. For further understanding of the plant and animal cytoskeleton and membrane structure and a full historical summary of their impact on virus movement, the following reviews are appropriate, in addition to those listed previously (Boevink and Oparka 2005; Epel 2009; Harries and Nelson 2008; Hofmann et al. 2007; Hussey et al. 2006; Jackson et al. 2009; Lucas et al. 2009; Marsh and Helenius 2006; Scholthof 2005; Verchot-Lubicz et al. 2007; Waigmann et al. 2004).

\section{VIRUS MOVEMENT AND MICROTUBULES}

\section{The interaction of Tobacco mosaic virus movement protein with microtubules.}

Numerous studies have shown that the movement protein (MP) of Tobacco mosaic virus (TMV) binds microtubules and
TMV RNA; thus, microtubules were considered to be the prime candidates for mediating the transport of the TMV RNA from replication sites to the PD (Heinlein et al. 1995, 1998; McLean et al. 1995; Padgett et al. 1996). Indeed, there was some association of the TMV replication complex with microtubules in tobacco protoplasts (Heinlein et al. 1998). Furthermore, it was shown that mutations in the MP that abolished microtubule association also abolished movement of TMV in either Nicotiana tabacum or N. benthamiana (Boyko et al. 2000, 2007). The interaction of the TMV MP with microtubules might be a case of molecular mimicry, because the MP contains motifs that are characteristic of tubulin. Viruses that contain point mutations in the tubulin motif of their MP exhibit reduced cell-to-cell spread and do not interact with microtubules, suggesting that the TMV MP-microtubule interaction is necessary for movement of the viral RNA (Boyko et al. 2000). Two models have been suggested for how the TMV RNA:MP complex would move on microtubules. The complexes could be actively transported on microtubules by kinesin motors, or the complexes could be propelled through the assembly of microtubules (Ouko et al. 2010).

Several recent articles have supported the model that MP aggregates might move as a consequence of the polymerization of microtubules. These studies emphasize the importance of focusing on the TMV MP-microtubule interaction that occurs in the leading edge of an infection (Boyko et al. 2007), because this is when the MP is associated with mobile particles on microtubules (Boyko et al. 2007; Sambade et al. 2008). In fact, there is general agreement that, late in infection, the MP becomes immobile on microtubules (Ashby et al. 2006; Boyko et al. 2007). Brandner and coworkers (2008) examined microtubule dynamics in cells located at the leading front of the infection, and found that MP interacts with green fluorescent protein (GFP)-tagged end-binding protein 1 (EB1a), a plant protein that accumulates at the plus end of microtubules. They suggested that the EB1/MP association could assist in formation or movement of TMV replication complexes. Furthermore, treatment of tissues with amiprofos-methyl, an herbicide that interferes with microtubule polymerization, inhibited the movement of TMV MP aggregates (Sambade et al. 2008). It was suggested that complexes composed of TMV RNA and MP initially associate with the ER, and these complexes then move to the PD utilizing both the ER and microtubules (Ouko et al. 2010; Sambade et al. 2008). Microtubules might also contribute to intracellular movement by anchoring these complexes for maturation. Intracellular movement could be driven by actin-dependent ER motility or through polymerization of microtubules (Brandner et al. 2008; Ouko et al. 2010; Sambade et al. 2008). In support of the latter model, Ouko and associates (2010) showed that a decrease in microtubule polymerization capacity was correlated with decreased virus movement.

However, other studies have questioned the role that microtubules play in trafficking TMV RNA or MP. For example, the microtubule network was disrupted through the use of the pharmacological agents colchicine, amiprophos-methyl, and oryzalin and also through silencing of the $\alpha$-tubulin gene with a Tobacco rattle virus vector, and these treatments did not inhibit movement of TMV (Gillespie et al. 2002; Kawakami et al. 2004). Similarly, oryzalin treatment did not inhibit movement of another member of the Tobamovirus genus, Turnip vein clearing virus (TVCV) (Harries et al. 2009b). It is important to note that not all pharmacological studies are in agreement. Seemanpillai and associates (2006) questioned the significance of experiments with microtubule inhibitors because they found that these agents did not efficiently disrupt the entire microtubule network in tobacco BY-2 cells. Furthermore, amipro- 
phos-methyl was shown to abolish the movement of TMV MP particles (Sambade et al. 2008) but, in another study, did not have an effect on movement of TMV, as assessed through the movement of TMV-MP-GFP in N. tabacum (Kawakami et al. 2004). Because the object of study differed in these two studies (movement of MP particles versus movement of virus), it may be that both are correct. Further work will be necessary to clarify the discrepancy in these results.

Because pharmacological approaches have led to conflicting results, complementary approaches designed to clarify the nature of the interaction between TMV MP and microtubules have been taken. These studies also yielded results suggesting that the interaction does not facilitate intercellular spread of the virus. For example, a mutant form of the MP, MPR3, had a strongly reduced affinity for microtubules but exhibited enhanced movement (Gillespie et al. 2002). In addition, the TMV MP physically interacts with the microtubule-associated protein (movement protein binding 2C [MPB2C]) originally identified from tobacco. In transient coexpression experiments of MPB2C with either TMV MP or the mutant MPR3, it was concluded that MPB2C actually reduced the intercellular transport of the TMV MP but had no negative effect on the mutant $\mathrm{MP}^{\mathrm{R} 3}$ (Kragler et al. 2003). Significantly, MPB2C did not bind to $\mathrm{MP}^{\mathrm{R} 3}$. In addition, silencing of MPB2C nearly abolished the localization of MP to microtubules but had no effect on the spread of either the TMV MP or of the virus (Curin et al. 2007). Similarly, overexpression of the Arabidopsis thaliana homolog of MPB2C in A. thaliana exhibited resistance to Oilseed rape mosaic virus, another relative to TMV in the Tobamovirus genus (Ruggenthaler et al. 2009). Collectively, these studies suggest that the interaction of Tobamovirus MP and microtubules, either directly or as directed by MPB2C, may not be involved in TMV intercellular movement. Instead, the interaction of MP with MPB2C might lead to an accumulation of an inactivated form of MP at microtubules (Curin et al. 2007; Gillespie et al. 2002; Ruggenthaler et al. 2009). Proponents of microtubule involvement in TMV movement have suggested that this interaction occurs late during infection, away from the cells where virus is actively moving (Boyko et al. 2007). Further work studying transport at the infection front will be necessary to fully understand the importance of microtubules or tubulin for TMV movement.

\section{Proteins of other plant viruses shown to associate with microtubules.}

In contrast with TMV MP, relatively little is known about the interactions of other plant virus proteins with microtubules. Although some plant virus proteins have been shown to interact with microtubules, there is little evidence in the literature to suggest a general role for microtubules in intracellular movement of plant viruses. It may be that this subject has not yet been fully explored, or it may be that microtubules are not necessary for intra- and intercellular movement of many plant viruses, unlike the situation for animal viruses (Greber and Way 2006). One possible reason for this difference may be the presence of PD in plant cells. PD are known to contain actin and ER (White et al. 1994; Overall and Blackman 1996) but have not been shown to contain tubulin or microtubules (walls enriched in PD contain tubulin but this tubulin is not necessarily in PD) (Blackman and Overall 1998). The plant virus proteins identified to date which interact with microtubules are summarized in Table 1 and each interaction is discussed below.

Three of the six proteins of Cauliflower mosaic virus (CaMV), a DNA virus, have been shown to associate with microtubules in plant cells. The P6 protein is a multifunctional protein whose documented activities include pathogenicity and avirulence determination, suppression of silencing, and trans- lational transactivation (Baughman et al. 1988; Love et al. 2007; Ryabova et al. 2002; Schoelz et al. 1986). It is also the major component of the electron-dense, amorphous inclusion bodies of CaMV. P6 has been found to associate with and stabilize microtubules in the presence of oryzalin, similar to TMV MP. However, P6 does not utilize microtubules for intracellular movement, raising the possibility that microtubules may be sites of P6 body assembly or degradation (Harries et al. 2009a). The P2 protein, a CaMV protein required for aphid transmission, forms electron-lucent inclusion bodies that also interact with microtubules, separate from the P6 inclusions (Blanc et al. 1996). The P3 protein colocalizes with microtubules through its interaction with the P2 protein rather than through a direct association with microtubules (Martinière et al. 2009). During initial infection, individual cells contain multiple small P2/P3 inclusions but, over time, they coalesce into a single electron-lucent inclusion. The development of the $\mathrm{P} 2 / \mathrm{P} 3$ inclusion bodies appears to require the presence of microtubules, because their formation in turnip cells was inhibited by oryzalin (Martinière et al. 2009). It has been inferred from the oryzalin treatments that P2 movement on microtubules is necessary for the formation of the P2/P3 inclusions (Martinière et al. 2009).

There are several examples in which components of plant virus virions have been associated with microtubules. Virions of Rice gall dwarf virus (RGDV) colocalize with microtubules in insect cells (Wei et al. 2009). Furthermore, colchicine and nocodazole blocked the release of RGDV virions from insect cells into the media, suggesting that these chemicals might interfere with the transport of virions from viroplasms to the plasma membrane (Wei et al. 2009). At this time, it is not known whether RGDV virions interact with microtubules in plant cells; thus, these findings currently have more relevance for the behavior of RGDV in the insect host cells because this virus replicates in both the insect and plant host. The Hsp70h protein of Beet yellows virus (BYV) is a minor but essential component of the BYV virions that is required for movement and is also a homolog of plant Hsp70 molecular chaperones (Peremyslov et al. 1999). The BYV Hsp70h was shown to bind microtubules in vitro (Karasev et al. 1992). However, in a later study, Hsp70h fused with red fluorescent protein did not colocalize with microtubules in $N$. benthamiana cells, and treatment of cells with oryzalin did not significantly inhibit trafficking of ectopically expressed Hsp70h to the cell periphery (Prokhnevsky et al. 2005). The authors concluded that microfilaments rather than microtubules are responsible for the movement of Hsp70h to the cell periphery. The coat protein and virions of Potato virus $X$ (PVX) also interact with microtubules in vitro but this association has not been confirmed in vivo (Serazev et al. 2003).

Microtubule-disrupting agents such as oryzalin have been used to infer associations of other plant virus proteins with microtubules, with both positive and negative results. For example, Grapevine fanleaf virus (GFLV) moves from cell to cell through MP-derived tubules in the form of virions. Oryzalin does not affect the formation of tubules in tobacco BY-2 suspension cells infected with GFLV but does influence the targeting of tubules from cross walls exclusively to additional peripheral locations, suggesting that proper targeting is dependent on the interaction of GFLV MP with microtubules (Laporte et al. 2003). In contrast, oryzalin had no effect on tubule formation in A. thaliana protoplasts that ectopically expressed the MP of CaMV or in cowpea protoplasts that expressed the MP of Cowpea mosaic virus (CPMV) Huang et al. 2000; Pouwels et al. 2002); therefore, it does not appear that the $\mathrm{MP} /$ microtubule association is universally required for cellto-cell movement of viruses. Similarly, Canto and Palukaitis 
spread. They observed that VRC, previously shown to associate with ER, moved to the PD, and demonstrated through pharmacological studies that intact microfilaments were necessary for TMV cell-to-cell movement in $N$. tabacum. Shortly after, Liu and associates (2005) demonstrated that VRC localize to and traffic along microfilaments in $N$. benthamiana. They also showed that the TMV $126-\mathrm{kDa}$ protein, which is a major constituent of VRC, can form cytoplasmic bodies and, when ectopically expressed, these 126-bodies can also traffic along microfilaments. The authors suggested that the $126-\mathrm{kDa}$ protein within the VRC may be the component that interacts with actin, either directly or indirectly, through its membrane interaction. Disruption of microfilaments with the inhibitor latrunculin B (LatB) inhibited both VRC and 126-body movement, and silencing of actin transcripts inhibited TMV intercellular spread, as evidenced by the reduced number of fluorescing cells in TMVGFP-induced fluorescent lesions (Liu et al. 2005). Recent work questioned the ability of LatB-mediated microfilament disruption to inhibit TMV intercellular movement in $N$. benthamiana (Hofmann et al. 2009). However, this study specifically exam- ined the short-term (24-h) effects of LatB. When longer LatB treatments were used (between 2 and 6 days), a clear negative effect of microfilament inhibition on sustained TMV movement was observed (Harries et al. 2009b; Kawakami et al. 2004; Liu et al. 2005). It is pertinent to note that, although the validity of using pharmacological cytoskeletal inhibitors to study virus movement has been questioned due to the possibility of incomplete effects (Seemanpillai et al. 2006) or pleiotropic effects, the recent work demonstrating the strong effect of LatB treatment on TMV movement also revealed a complete insensitivity to LatB of the closely related Tobamovirus sp., TVCV, in N. benthamiana (Harries et al. 2009b). This striking difference between two members of the same genus strongly suggests that any effect of LatB on TMV movement is not due to pleiotropic inhibition of virus replication through a general inhibition of cell metabolism. This work further demonstrates that even closely related viruses may differ greatly in their requirements for movement. Although the mechanism of TVCV's intercellular spread remains unknown, it was found that the TVCV $125-\mathrm{kDa}$ protein does not form cytoplasmic bodies like the TMV 126-

Table 1. (continued from preceding page)

\begin{tabular}{|c|c|c|c|}
\hline Virus $^{\mathbf{b}}$ & $\begin{array}{l}\text { Protein or } \\
\text { RNA }^{c}\end{array}$ & Nature of interactions & References \\
\hline PNRSV & MP & $\begin{array}{l}\text { Hydrophobic domain that interacts with membrane interface; helicity and } \\
\text { hydrophobicity regions needed for virus movement }\end{array}$ & Martínez-Gil et al. 2009 \\
\hline RCNMV & MP & Localizes with ER during RNA 1 replication & Kaido et al. 2009 \\
\hline GFLV & MP & $\begin{array}{l}\text { Localization disrupted by BFA treatment and cofractionates and coim- } \\
\text { munoprecipitates with membrane protein KNOLLE }\end{array}$ & Laporte et al. 2003 \\
\hline \multirow[t]{2}{*}{ BYV } & MP & $\begin{array}{l}\text { Localizes to ER and mutagenic analysis indicates this is essential for } \\
\text { virus movement }\end{array}$ & Peremyslov et al. 2004 \\
\hline & Hsp70h & Localizes at modest levels to vesicles and chloroplasts & Medina et al. 1999 \\
\hline TEV & P3 & Localized to ER and traffics to Golgi & Cui et al. 2010 \\
\hline TuMV & $6 \mathrm{~K}_{2}$ & Traffics from ER to chloroplasts and forms invaginations & Cotton et al. 2009; Wei et al. 2010 \\
\hline TCV & $\mathrm{p} 9$ & Associates with ER-derived membrane & Martínez-Gil et al. 2010 \\
\hline MNSV & p7B & $\begin{array}{l}\text { Associates with ER and Golgi and BFA inhibits movement to PD. Virus } \\
\text { intercellular movement also inhibited by BFA treatment }\end{array}$ & Genovés et al. 2010; Martínez-Gil et al. 2007 \\
\hline CarMV & p9 & Associates with ER & Vilar et al. 2002 \\
\hline \multirow[t]{2}{*}{ PVX } & TGBp2 & $\begin{array}{l}\text { Colocalizes with ER and not Golgi and mutations disrupt ER association } \\
\text { and trafficking }\end{array}$ & Mitra et al. 2003; Ju et al. 2005, 2007 \\
\hline & TGBp3 & Localizes with ER and mutations disrupt association & $\begin{array}{l}\text { Krishnamurthy et al. 2003; Bamunusinghe et } \\
\text { al. } 2009\end{array}$ \\
\hline \multirow[t]{2}{*}{ PSLV } & TGBp2 & Colocalizes with ER & Solovyev et al. 2000; Zamyatnin et al. 2002 \\
\hline & TGBp3 & $\begin{array}{l}\text { Colocalizes with ER but does not require COPII-mediated transport } \\
\text { system to get to PD }\end{array}$ & $\begin{array}{l}\text { Zamyatinin et al. 2002; Gorshkova et al. 2003; } \\
\text { Schepetilnikov et al. } 2008\end{array}$ \\
\hline \multirow[t]{2}{*}{ PMTV } & TGBp2 & $\begin{array}{l}\text { Colocalizes with ER. Mutations within disrupt its association and PD } \\
\text { targeting. Also associate with endosome marker and endocytic } \\
\text { trafficking J-domain chaperone }\end{array}$ & Cowan et al. 2002; Haupt et al. 2005 \\
\hline & TGBp3 & $\begin{array}{l}\text { Colocalizes with ER and mutation disrupts this association and virus } \\
\text { movement }\end{array}$ & Cowan et al. 2002; Tilsner et al. 2010 \\
\hline BaMV & TGBp2 & Associates with membrane & Hsu et al. 2008 \\
\hline GRSPaV & $\begin{array}{l}\text { TGBp2 } \\
\text { TGBp3 }\end{array}$ & $\begin{array}{l}\text { Colocalizes to ER and ER-derived structures } \\
\text { Colocalizes to ER }\end{array}$ & $\begin{array}{l}\text { Rebelo et al. } 2008 \\
\text { Rebelo et al. } 2008\end{array}$ \\
\hline BSMV & TGBp2 & $\begin{array}{l}\text { Colocalizes to ER, chloroplast and other membranes; Ratios of TGBp2 to } \\
\text { TGBp3 expression influence location of TGBp2 }\end{array}$ & Lim et al. 2009; Torrance et al. 2006 \\
\hline BNYVV & $\begin{array}{l}\text { TGBp1 } \\
\text { TGBp2 } \\
\text { TGBp3 }\end{array}$ & $\begin{array}{l}\text { Localizes to membrane-rich peripheral bodies } \\
\text { Localizes to membrane-rich peripheral bodies } \\
\text { Localizes to membrane-rich peripheral bodies }\end{array}$ & $\begin{array}{l}\text { Erhardt et al. } 2005 \\
\text { Erhardt et al. } 2005 \\
\text { Erhardt et al. } 2005\end{array}$ \\
\hline BBWV & VP37 & Colocalizes with ER and moves within cell & Liu et al. 2009a \\
\hline TSWV & Gn and Gc & $\begin{array}{l}\text { Associates with ER export site and Golgi and mutation of Gn transmem- } \\
\text { brane domain or inhibition of Golgi transport modifies their subcellular } \\
\text { localization }\end{array}$ & Ribeiro et al. 2009 \\
\hline SYNV & M & Associates with bud from nucleus and moves to ER & Goodin et al. 2007 \\
\hline SPMV & $\mathrm{CP}(\mathrm{N}-\mathrm{ARM})$ & Associates with membrane fraction & Qi et al. 2008 \\
\hline AbMV & NSP and MP & $\begin{array}{l}\text { Localize to cytoplasmic space of plasma membrane when expressed } \\
\text { together }\end{array}$ & Frischmuth et al. 2007 \\
\hline $\mathrm{CaLCuV}$ & MP & $\begin{array}{l}\text { Binds synaptotagmin SYTA, which associates with endosomes and other } \\
\text { membranes. }\end{array}$ & Lewis and Lazarowitz 2010 \\
\hline SqLCV & MP & $\begin{array}{l}\text { Binds synaptotagmin SYTA, which associates with endosomes and other } \\
\text { membranes. }\end{array}$ & Lewis and Lazarowitz 2010; Ward et al. 1997 \\
\hline CaMV & MP & Localization disrupted by BFA treatment & Huang et al. 2000 \\
\hline
\end{tabular}


$\mathrm{kDa}$ protein (Harries et al. 2009b) suggesting that the formation of cytoplasmic bodies by Tobamovirus spp. is linked to microfilament-dependent virus movement.

\section{Evidence for the involvement of microfilaments in movement of other viruses.}

In addition to the TMV $126-\mathrm{kDa}$ protein, proteins from a diverse array of plant viruses have been found to form granules or inclusions that localize to or traffic along microfilaments (Table 1). For example, PVX requires intact microfilaments for its sustained cell-to-cell spread and the PVX movement-associated protein, TGBp2, forms granules that colocalize with microfilaments (Harries et al. 2009b; Ju et al. 2005). Similarly, both TGB2 and TGB3 from Potato mop-top virus (PMTV) form motile granules that colocalize with microfilaments and whose movement is inhibited by LatB treatment in N. tabacum (Haupt et al. 2005). Interestingly, TGBp3 from Poa semilatent virus does not appear to utilize the cytoskeleton to reach $\mathrm{PD}$, as shown through inhibitor analysis (Schepetilnikov et al. 2008). Data also are emerging that movement of Potyvirus VRC may depend upon microfilaments. Turnip mosaic virus (TuMV) VRC are induced to form at the ER membrane by the viral $6 \mathrm{~K}_{2}$ protein. When TuMV containing a $6 \mathrm{~K}_{2}$ fluorescent fusion was introduced into $N$. benthamiana, motile fluorescently tagged VRC were found to colocalize with microfilaments, and the movement of these VRC was inhibited by LatB (Cotton et al. 2009). In addition, the P3 protein from the Potyvirus sp. Tobacco etch virus forms punctate bodies that localize to and traffic along microfilaments in N. benthamiana (Cui et al. 2010). Although the exact role of this protein remains to be elucidated, it also localizes to the ER and may play some role in virus replication or VRC formation.

Although little information is available regarding the movement of plant DNA viruses, it was recently demonstrated that inclusion bodies formed by the CaMV P6 protein are motile and can traffic along microfilaments (Harries et al. 2009a). Although no role for P6 in movement has been previously shown, P6 is known to be capable of shuttling itself out of the nucleus (Haas et al. 2005). The movement of P6-bodies is eliminated by LatB treatment in $N$. benthamiana, as is the ability of CaMV to form necrotic local lesions on N. edwardsonii (Harries et al. 2009). This lack of lesion formation is likely due to an inhibition of virus movement by LatB, although further work must be done to differentiate the effect of LatB on virus movement and accumulation.

In some cases, the direct association of specific viral proteins with microfilaments has not been determined but disruption of microfilaments is known to inhibit virus intercellular spread or the intracellular localization of specific viral proteins. For example, LatB treatment disrupts the sustained intercellular movement of Tomato bushy stunt virus (TBSV) but the specific TBSV proteins that may interact with microfilaments are unknown (Harries et al. 2009b). In the case of Potato leafroll virus, it is not yet known whether cell-to-cell spread requires microfilaments; however, LatB treatment has been shown to inhibit the localization of MP to PD in Arabidopsis, suggesting that this may be the case (Vogel et al. 2007). Viral MP have long been known to increase the size exclusion limits (SEL) of PD (Waigmann et al. 2004) and it was recently shown that the MP of both CMV and TMV possess the ability to sever microfilaments in vitro. If this ability is blocked, by either MP mutants or pharmacological stabilization of microfilaments, then the MP lose their ability to increase the SEL of PD in N. benthamiana (Su et al. 2010). Interestingly, the microfilament severing ability displayed by the CMV and TMV MP did not occur in the cytoplasm. The authors suggested that the transport form of these proteins inhibited severing activity until they reached the PD. These findings provide important insight into the role of MP and microfilaments in intercellular virus movement.

Although actin has been implicated in the movement of many diverse plant viruses, the role of specific myosin motor proteins in this process has only begun to be elucidated. The movement of BYV is known to require five viral proteins, including the heat shock protein homolog, Hsp70h (Peremyslov et al. 1999). This protein localizes to the PD and forms motile granules that associate with microfilaments in $N$. benthamiana (Prokhnevsky et al. 2005). The movement of Hsp70h to PD was inhibited by treatment with either LatB or BDM, an ATPase inhibitor known to disrupt myosin function (Prokhnevsky et al. 2005). It was further shown that inhibition of class VIII myosins via overexpression of myosin tail domains could block Hsp70h PD localization (Avisar et al. 2008). Importantly, inhibition of class XI myosins did not interfere with Hsp70h localization, indicating a preferential interaction of this viral protein with a specific class of myosins. In addition, these studies revealed that the localization of TMV MP to PD was not affected by inhibition of class VIII myosins.

In recent work, individual $N$. benthamiana myosins were inhibited via virus-induced gene silencing (VIGS) and the effect on sustained cell-to-cell movement of several diverse viruses were observed (Harries et al. 2009b). Silencing of a specific myosin XI (XI-2) significantly inhibited TMV intercellular spread while inhibition of several other myosins (XI-F, VIII-1, and VIII-2) did not reduce TMV movement. Interestingly, myosin XI-2 silencing did not inhibit the spread of either PVX or TBSV, both of which were shown to require intact microfilaments for sustained cell-to cell movement (Harries et al. 2009b). These findings further suggest that different viruses may utilize different myosins for their movement or the movement of their encoded proteins. It will be important to identify these myosins and to determine whether TMV or any other virus truly uses only one myosin for intracellular transport functions or if others remain to be identified.

It is interesting that recent work has shown that overexpression of another actin-binding protein, the actin-binding domain of fimbrin, decreased intercellular movement of TMV (Hofmann et al. 2009). These authors suggested that the decrease in TMV movement was due to reduced fluidity of the membrane, which they speculated was the primary conduit for TMV movement. This again indicates the difficulty in separating the functions of microfilaments and their associated proteins and membranes for virus intracellular and intercellular movement.

It is pertinent to note that the interaction of viral proteins with the cytoskeleton is not confined to a plant host. Many viruses must undergo complex interactions with insect vectors that may then transmit them from plant to plant. For example, the Pns10 protein from Rice dwarf virus was found to interact with actin structures within its insect vector (Table 1) (Wei et al. 2006, 2008). It will be interesting to determine whether such interactions are distinct for each host or whether individual proteins may similarly interact with actin in both insects and plants.

\section{VIRUS MOVEMENT AND HOST MEMBRANES}

\section{Linkage between virus replication and movement.}

The membrane system is the third member of the triad of host macromolecular complexes that influences virus movement. The replication-associated proteins encoded by members of the plant alphavirus-like group provide an example of the complexity and continuing mystery of virus protein-membrane interactions and this requirement for virus movement. 
The Brome mosaic virus (BMV) 1a protein contains methyltransferase and helicase domains and is known to associate with the ER in yeast and barley plant cells (Restrepo-Hartwig and Ahlquist 1996; L. Liu. et al. 2009), whereas the apparent homologs of this protein encoded by Alfalfa mosaic virus (AlMV) and CMV localize with vacuolar membranes in leaf cells of N. tabacum and Cucumis sativus, and protoplasts of Vigna unguiculata, respectively (Van Der Heijden et al. 2001; Cillo et al. 2002). Intriguingly, another homolog, the TMV $126-\mathrm{kDa}$ protein and some of its Tobamovirus homologues, were shown to associate with membranes including the ER and vacuole within cells of solanaceous hosts, likely through a host anchor protein referred to as TOM1 (Heinlein et al. 1998; Más and Beachy 1999; Yamanaka et al. 2000; dos Reis Figueira et al. 2002; Hagiwara et al. 2003; Nishikiori et al. 2006). These findings suggest that the $126-\mathrm{kDa}$ protein resides in multiple membrane types at one time or different membranes over time during the infection cycle, almost certainly as part of the VRC described in the section on virus movement and microfilaments. Of these homologs, only the TMV 126-kDa protein and CMV 1a protein are known to be necessary for intercellular movement through genetic analysis (Gal-On et al. 1994; Hirashima and Watanabe 2001, 2003) and only the 126-kDa protein and the TMV VRC, containing the $126-\mathrm{kDa}$ protein, are known to move intracellularly (Liu et al. 2005). It might be assumed that the BMV or AlMV 1a homologs move intracellularly or are important for virus movement like the TMV and CMV homologs; however, this may be a dangerous assumption because these proteins can have unique functions. For example, the TMV 126-kDa protein is a suppressor of RNA silencing (Ding et al. 2004) whereas the BMV 1a protein apparently does not have this activity (Gopinath et al. 2005). These results indicate the difficulty in teasing apart virus movement and replication activities for just one family of virus protein homologs that associate with membranes! Plant virus proteins (as free protein or fused with a reporter) that are i) necessary for virus movement or ii) move within cells during ectopic expression or virus infection, and which associate with membranes, are listed in Table 1. Because many virus MP have been shown to associate with membranes and these interactions have been reviewed previously, we do not review this literature in detail here but include a reference list in the table for those interested in specific information for their MP of interest.

Chaperones such as those from the Hsp70 and -40 families that interact with virus membrane-associated proteins represent another difficult situation where movement and replication functions and the impact of membranes on these activities become difficult to separate. Multiple studies have shown an association between chaperones and virus replication and movement proteins (Serva and Nagy 2006; von Bargen et al. 2001; Wang et al. 2009). In Tombusvirus studies, it is a cellular rather than a membrane-associated chaperone that associates with the replication complex. It was hypothesized that the cellular chaperones were necessary to allow the refolding of the virus replication proteins for insertion into the peroxisomal membrane in yeast cells. Later, it was demonstrated that, without this refolding, the virus replication complex was not localized to the membrane (Wang et al. 2009). Thus, if one considers the intracellular positioning of the replication complex as movement, this is a movement defect. Considering the breadth and complexity of other such interactions, we will not further consider these types of interactions in this review; however, the association of chaperones with viral movement proteins and their importance in virus movement remains of interest here. The association of chaperones having DnaJ-like properties with the MP of Tomato spotted wilt virus (TSWV) and TMV suggests the potential that individual MP can require proper folding for their movement function (von Bargen et al. 2001; Shimizu et al. 2009). The Hsp70h protein of BYV associates with the cell wall and with various membranes in $N$. benthamiana (Medina et al. 1999). Although the Hsp70h protein may use microfilaments to traffic to the wall (Avisar et al. 2008; Prokhnevsky et al. 2005;), it is proposed that the Hsp70h anchors on a membrane at that site and serves to pull the virion through the PD through ATP hydrolysis through studies with N. tabacum protoplasts and Claytonia perfoliata (Alzhanova et al. 2001).

\section{Role of membranes in movement early and late during infection.}

For some viruses, more is understood about their membrane interactions and that relationship with virus movement. The following sections will discuss the various temporal stages of virus infection and spread and highlight pertinent virus proteinhost membrane interactions. As viruses infect cells, they must initially become attached to a membrane system for translation and replication to proceed. This has been a very understudied area but, recently, an enlightening study reported that fluorescently labeled viral TMV RNA formed granules that anchored to the cortical actin-ER network within minutes of injection in Nicotiana spp. (Christensen et al. 2009). The granules were capable of intracellular movement and the 5 ' methylguanosine cap was essential to anchor the granule to the actin-ER network and protect it from degradation. Replication was not needed for this activity. These results clearly illustrate that we must consider not only the transport of the viral RNA from the replication site to the cell wall for movement but also the initial transport of infectious RNA to the replication site as an intracellular movement phenomenon. These granules may be precursors to the mobile MP granules that associate with microtubules (Sambade et al. 2008) or to the VRC that associate with the ER-actin network or microtubules and ER (Heinlein et al. 1998; Liu et al. 2005) (Fig. 1).

As noted earlier, virus replication complexes are associated with various membranes, including the ER, vacuole, peroxisome, and chloroplast (Sanfaçon 2005). Both the virus RNA, perhaps as part of a replication complex, and individual virus proteins must move from these sites to the cell wall to support virus intercellular movement. In few instances has this been studied for plant viruses. Several recent studies indicate a mixed requirement for COPII-mediated export from the ER of individual virus proteins. The envelope glycoproteins, Gn and Gc, from TSWV are critical for the intracellular assembly of the virus particle at the Golgi complex, and it has been shown that Gn alone or Gc in the presence of Gn can traffic from the ER to the Golgi complex in $N$. tabacum protoplasts (Ribeiro et al. 2008). In a recent study, this transport was shown to be through a COPIIdependent process through brefeldin A (BFA) treatment and dominant-negative Sar1 GTPase overexpression studies (Ribeiro et al. 2009). Similarly, the membrane-associated MP of Melon necrotic spot virus (MNSV) also was shown to utilize the COPII vesicle trafficking system to reach the PD. In a rare case where individual virus protein movement was studied together with virus movement, inhibition of MNSV MP transport was linked to inhibition of virus intercellular movement in $N$. benthamiana (Genovés et al. 2010). For several Potyvirus spp., ectopically expressed $6 \mathrm{~K}_{2}$ protein associated with ER exit sites and, for TuMV $6 \mathrm{~K}_{2}$ protein, mobile vesicles associated with a Golgi complex marker, ERD2, in N. benthamiana (Wei et al. 2010). In addition, as for the other proteins mentioned above, the Sar1 mutant inhibited accumulation of the $6 \mathrm{~K}_{2}$ protein in membranes other than the ER. Interestingly, under normal conditions, the $6 \mathrm{~K}_{2}$-containing vesicles ended up associated with chloroplasts. The P3 protein, encoded by another Potyvirus sp., Tobacco etch 
virus, also trafficked in a manner mediated by COP II vesicles and colocalized with $6 \mathrm{~K}_{2}$-induced vesicles in $N$. benthamiana (Cui et al. 2010). However, for some virus proteins, the COPII transport system does not seem to be important. For example, the TMV MP and the PVX and PMTV movement-associated proteins TGBp2 and TGBp3 all seem to move to the wall via a Golgi-independent pathway in various Nicotiana spp. (Haupt et al. 2005; Ju et al. 2005; Schepetilnikov et al. 2005; Tagami and Watanabe 2007; Wright et al. 2007). Thus, it is clear that transport of virus proteins to the cell periphery can use different host transport systems.

A dichotomy in movement requirements between viruses within a family involves members of the Comoviridae. CPMV $60-\mathrm{kDa}$ protein is associated with proliferating ER membranes during virus accumulation in $N$. benthamiana and $V$. unguiculata cells and with SNARE-like proteins through yeast twohybrid studies (Carette et al. 2000, 2002). The 60-kDa protein has not been shown to be associated with virus intracellular or intercellular movement; however, SNARE proteins are involved in membrane targeting and fusion events (Lipka et al. 2007; Moreau et al. 2007). Ecotopic expression of the MP of this virus indicated that this protein requires neither the cytoskeleton nor the COPII pathway to reach the cell wall (Pouwels et al. 2002). Thus, with one protein not associated with virus movement but associated with a membrane fusion protein and a second associated with virus movement but not the cytoskeleton or membranes associated with the COPII pathway, it remains a mystery how CPMV and its components move within cells after initial membrane association. A second member of the Comoviridae family, GFLV, also causes proliferation of the ER, and its MP also ends up in the cell periphery in $N$. tabacum cells (Ritzenthaler et al. 2002). However, unlike the MP of CPMV, localization of this MP was inhibited by BFA treatment and it was found to coprecipitate with a membrane protein, KNOLLE (Laporte et al. 2003). Recently, this MP was shown to interact with a PD-specific host protein, thus indicating a potential functional end point for MP trafficking for this virus (Benitez-Alfonso et al. 2010). Therefore, for this member of the Comoviridae family, membranes associated with the COPII pathway are important for the function of the MP, which must get to the PD to support virus movement.

After leaving the membranes associated with virus replication for other intracellular destinations, there is likely the need to recycle components back to internal membranes, as is known to occur for many plant factors (Murphy et al. 2005). Recent studies have demonstrated this activity for several plant virus proteins. TGBp2 of PMTV was shown to be present in vesicles within $N$. benthamiana cells labeled with FM4-64, a marker for PM internalization (Haupt et al. 2005). These researchers also determined that TGBp2 from this virus colocalizes in vesicles with a Rab6 ortholog that marks the early endosome and interacts with a protein belonging to a conserved family of J-domain chaperones essential for endocytic trafficking in Caenorhabitis elegans and Drosophila melanogaster. For TBSV, ectopic expression of the p33 replication protein was found to move from the peroxisome membrane to a peroxisomal ER subdomain in $N$. tabacum cells (McCartney et al. 2005). Interestingly, the p33 protein also interacts with endosomal sorting complexes required for transport proteins (Barajas et al. 2009). These proteins were suggested to be necessary for the correct assembly of the replicase complex.

\section{Regulated movement of virus replication complexes on membranes.}

One topic not addressed in much detail for plant viruses is the potential of virus protein or complex movement within mem- branes as opposed to cytoskeletal-mediated movement. For example, within the ER, can virus protein or complex movement proceed for long distances, not only by cytoskeleton-mediated remodeling of the ER but by regulated movement within the membrane itself? In addition, can protein and lipid components alter the virus transport within the membrane? Membrane diffusion velocities for ER-localized GFP fusion proteins range from 0.2 to $0.5 \mu \mathrm{m}^{2} \mathrm{~s}^{-1}$ (Lippincott-Schwartz et al. 2001). Although this is much slower than microfilament-mediated movement velocities for organelles ( $4 \mu \mathrm{m} \mathrm{s}^{-1}$ ) (Nebenführ et al. 1999), it is well within the range noted for microtubule-mediated movement (e.g., approximately $0.04 \mu \mathrm{m} \mathrm{s}^{-1}$ ) (Cai et al. 2000) and especially for virus intercellular spread ( $4 \mathrm{~h}$ or more from initially infected cells and 5 to $7 \mathrm{~h}$ to subsequent cells) (Derrick et al. 1992; Fry and Matthews 1963). Studies with TMV have shown that expression of the TMV MP and replicase-associated proteins (the 126- and $183-\mathrm{kDa}$ proteins) are necessary to allow maximum movement of the fluorescently labeled membrane-associated ER markers, Calnexin:GFP and ACA2:GFP, between cells (Guenoune-Gelbert et al. 2008). Thus, if virus replication complexes require membranes for their intercellular movement, their ability to efficiently move between cells requires the expression of multiple TMV proteins. Hofmann and associates (2009) suggested that membrane fluidity was important for TMV movement after determining that overexpression of the actin-binding domain of fimbrin inhibited TMV movement in $N$. benthamiana cells. They hypothesized that the excess fimbrin was overly anchoring membrane components and preventing transport of virus complexes through the ER. Certainly, the absence of an effect on sustained TVCV intercellular movement after treatment with microtubule and microfilament antagonists suggests that membranes have an important role in the spread of this virus (Harries et al. 2009b).

A second interesting observation regarding the effect of membrane components on virus spread involves the influence of a small hydrophilic plasma membrane protein, remorin, on virus intercellular movement (Raffaele et al. 2009). The remorin family consists of more than 100 proteins and those associated with detergent-insoluble membranes (thought to be biochemical representatives of lipid rafts) belong to group $1 \mathrm{~b}$. These authors demonstrated that a group $1 \mathrm{~b}$ solanaceous remorin resides in 70-nm membrane domains similar to lipid rafts and that the movement of PVX is inversely related to remorin accumulation in Solanum lycopersicum. They also demonstrated a physical interaction between the TGBp1 protein of PVX and remorin. This may be an example where a membrane-associated interaction between a host and viral protein inhibits virus movement.

\section{CONCLUDING THOUGHTS: QUESTIONS TO BE RESOLVED}

Plant virologists and biologists have made tremendous progress in the last 5 to 10 years toward understanding movement of viruses in plants. We have moved far beyond the initial identification of MP and an analysis of their effect on SEL of the PD to the analysis of virus protein interactions with the host cytoskeleton and membranes and how these interactions facilitate virus movement. A basic outline of what we know in this area is provided in Figure 1, from which more specific models can be built. Even in this early stage of investigation, there appears to be no unified mechanism by which viruses move within and between cells. A remarkable example supporting this conclusion is the finding that TVCV does not appear to use any cytoskeletal element, microfilament or microtubule, for its sustained intercellular movement whereas TMV, a virus from the same genus, utilizes microfilaments and myosin XI-2 
for its movement (Harries et al. 2009b). Another important consideration is the possibility that a single virus may opportunistically use different movement mechanisms in different host plants. Clearly, plant viruses have explored and continue to explore the evolutionary limits available to them within the host cytoskeleton and membrane systems to move within and between cells. Studies of a diverse range of these viruses in a number of different hosts will likely reveal the extent of this exploration and perhaps serve as a model for plant biologists studying intracellular and intercellular movement of plant proteins and nucleic acids. In addition, results from these studies will provide insights into new methods to produce more disease-resistant plants by restricting virus movement. However, protection methods are likely to be successful against only sin- gle or small related groups of viruses, considering the diversity of mechanisms for virus movement. To reach a fuller understanding of virus spread, however, multiple questions about the mechanisms of virus intra- and intercellular movement remain to be answered.

One issue that should be apparent from this review (and especially from the information in Table 1) is that most individual virus proteins remain untested or poorly characterized for their individual capacity to associate with the cytoskeleton or membranes or to move within a cell. For example, the replicase of PVX associates with the ER (Bamunusinghe et al. 2009); however, does it have the capacity for cytoskeleton association which could support vRNA movement to the PD? It is clear that considerable work remains to be done to identify the virus

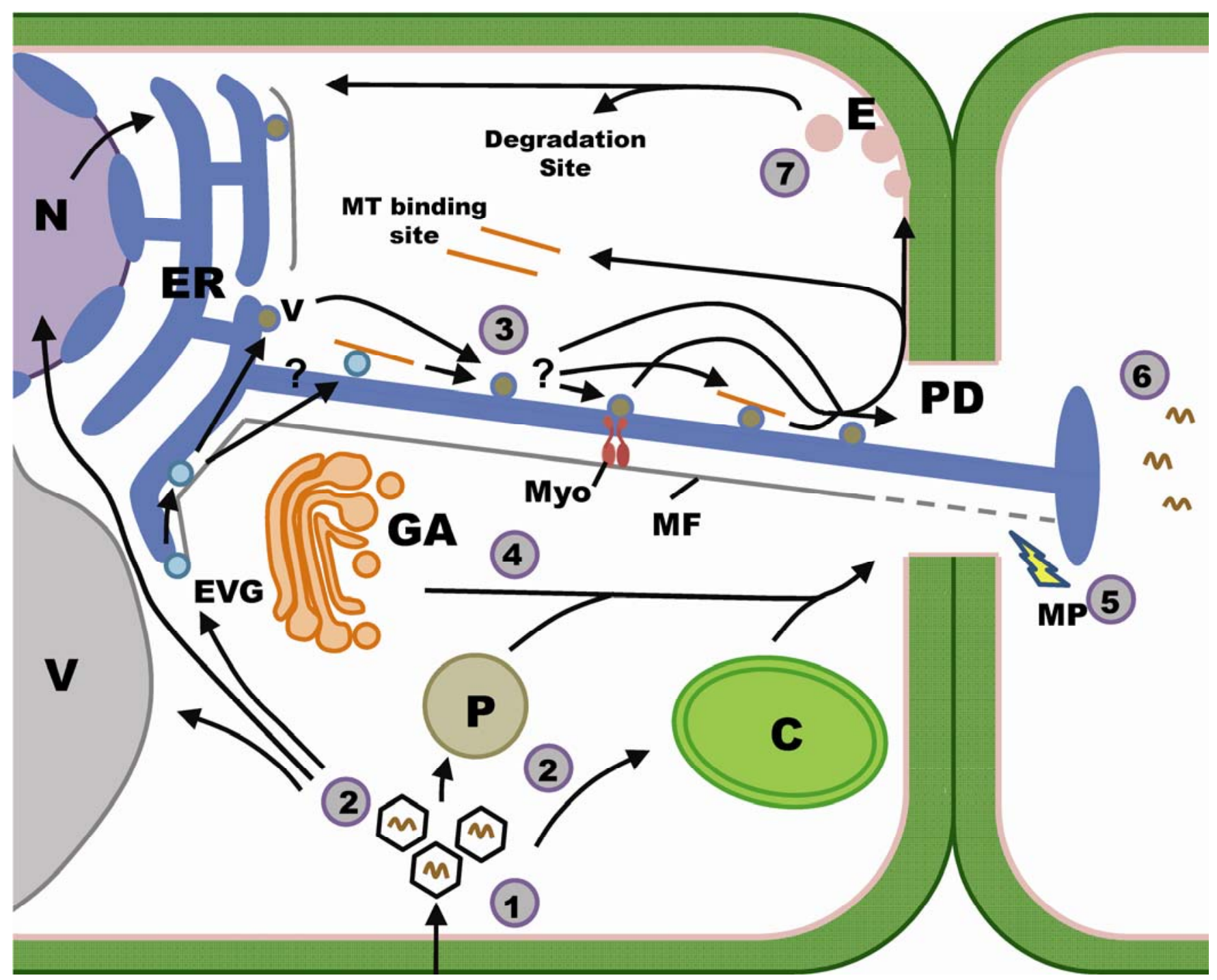

Fig. 1. Pathways for virus and virus component movement in plant cells. Upon entry into the cell by wounding or insect transmission (1), viral nucleic acid is released from its capsid and moves to cellular membranes (2) which serve as sites of replication. Membrane-bound organelles such as the chloroplast (C), peroxisome $(\mathrm{P})$, vacuole $(\mathrm{V})$, and endoplasmic reticulum (ER) each may be targeted by certain viruses. Viral nucleic acid may move to membranous replication sites alone or in the form of early virus granules (EVG). In the case of certain DNA viruses, the nucleic acid moves into the nucleus for replication. In order to spread from cell to cell, viral components must then move from membranous sites of replication or the nucleus to the cell wall (3 and 4). These components may move alone or as a part of virus replication complexes (V). Movement of virus complexes or virus proteins may proceed via the actin-ER network or via microtubules (MT, indicated by tan bars) and ER during or after virus complex maturation (3) (e.g. Tobacco mosaic virus; to be determined if all these pathways function in situ), or via membrane alone (e.g. Turnip vein clearing virus). Alternatively, virus or virus components may move through a Golgi apparatus (GA)-mediated pathway (4) (e.g. movement protein [MP] of Melon necrotic spot virus). Movement along microfilaments (MF) may be driven by myosins (Myo). For certain viruses, the MP may sever MF or actin structures at the plasmodesmata (PD) to facilitate PD opening (5). Some viral components (RNA, protein, or both) are transferred to the next cell (6) whereas other components are recycled through an endocytic pathway or possibly directly onto MT (7). Endosomes (E) move back to the ER where viral proteins can be reused. Alternatively, endosomes target their cargo for degradation. Although a direct link between MT binding and MP degradation has not been shown, the binding of MP with MT is correlated with subsequent disappearance of MP in cells. Viral inclusions may also be degraded through similar pathways, particularly later in the infection process, possibly as part of a plant defense response. 
proteins that interact with the cytoskeleton and membranes and how they move within the cell.

Additionally, we must increase our knowledge of how the movement and localization of specific virus proteins is related to virus movement. For example, very recently it was shown that there is a positive relationship between the requirement of the ER to Golgi transport system for MNSV p7B protein and virus movement (Genovés et al. 2010). However, the movement of a single virus protein or complex may not always be directly involved in virus movement. It is not implausible to consider that the TMV VRC, which contain the 126-kDa protein, induce a defense response in the host that inhibits virus movement. The virus may use the cytoskeleton to position the VRC in a location that inhibits or prevents the response, thus allowing continued intracellular movement by the virus. The TVCV VRC does not form large or numerous inclusions and, thus, would not require this cytoskeleton-mediated localization activity to allow its continued movement.

Finally, with the vast wealth of information regarding the importance of membranes and cytoskeleton in movement, we must strive to gain a better understanding of the interactions between these cellular elements. This may best be illustrated by the difficulty in explaining the roles of microtubules, microfilaments, and membranes for TMV movement. Sustained intercellular movement by TMV from 2 to 6 days postinoculation requires an intact microfilament array (Harries et al. 2009b). However, in a different study, it was concluded that TMV does not require an intact microfilament array for movement in the first $24 \mathrm{~h}$ after treatment with LatB (Hofmann et al. 2009). Pharmacologically based studies also were interpreted to substantiate (Sambade et al. 2008) or eliminate (Gillespie et al. 2002) the role of microtubules in TMV movement. Regardless of this discrepancy, it is clear that TMV MP granules traffic on cortical microtubules (Boyko et al. 2007; Sambade et al. 2008) and the impact of this activity on TMV movement is under study (Ouko et al. 2010). The articles studying the influence of microfilaments on TMV movement noted that the differing times when observations were made could influence the interpretation of the results. It previously was shown that antagonists of microfilaments increase the SEL of PD (Ding et al. 1996). This modification might enhance movement over the short term while inhibiting movement on microfilaments over the long term. Recently, it was demonstrated that the TMV MP, which may move to the cell wall in the absence of intact microfilaments (Prokhnevsky et al. 2005) and separately from the vRNA, has in vitro microfilament severing activity ( $\mathrm{Su}$ et al. 2010). These authors noted that microfilaments were not severed in the cell cytoplasm and they speculated that the severing activity occurred only after a structural rearrangement of the MP at the cell wall. Thus, it is possible that TMV both utilizes microfilaments in the cytoplasm and destroys actin structures associated with the PD for virus movement. In the PD, the vRNA may not utilize actin to move between cells, instead moving within a membrane complex in the ER, as suggested by Guenoune-Gelbart and associates (2008). Thus, TMV could use both cytoskeleton and membranes for its intercellular movement through spatially and temporally separate activities. Clearly, even with the wealth of information available for TMV, we are not close to understanding the mechanism and regulation of its movement within and between cells. Only if all of the challenges described here are met will we begin to fully understand the complex picture of plant virus movement.

\section{ACKNOWLEDGMENTS}

We thank P. Xu and E. Blancaflor for critically reading the manuscript and A. Maule and C. Ritzenthaler for comments on the article and for sharing prior access to their companion article in this issue of the journal. This work was supported in part by a National Institute For Food and Agriculture Award (award no. 2010-65108-20525 to J. E. Schoelz and R. S. Nelson) and The Samuel Roberts Noble Foundation, Inc. (to R. S. Nelson).

\section{LITERATURE CITED}

Alzhanova, D. V., Napuli, A. J., Creamer, R., and Dolja, V. V. 2001. Cellto-cell movement and assembly of a plant closterovirus: Roles for the capsid proteins and Hsp70 homolog. EMBO (Eur. Mol. Biol. Organ.) J. 20:6997-7007.

Ashby, J., Boutant, E., Seemanpillai, M., Sambade, A., Ritzenthaler, C., and Heinlein, M. 2006. Tobacco mosaic virus movement protein functions as a structural microtubule-associated protein. J. Virol. 80:83298344.

Avisar, D., Prokhnevsky, A. I., and Dolja, V. V. 2008. Class VIII myosins are required for plasmodesmatal localization of a closterovirus Hsp70 homolog. J. Virol. 82:2836-2843.

Bamunusinghe, D., Hemenway, C. L., Nelson, R., Sanderfoot, A. A., Ye, C. M., Silva, M. A. T., Payton, M., and Verchot-Lubicz, J. 2009. Analysis of Potato virus $X$ replicase and TGBp3 subcellular locations. Virology 393:272-285.

Barajas, D., Jiang, Y., and Nagy, P. D. 2009. A unique role for the host ESCRT proteins in replication of Tomato bushy stunt virus. PLoS Pathog. 5:e1000705. Published online.

Baughman, G. A., Jacobs, J. D., and Howell, S. H. 1988. Cauliflower mosaic virus gene VI produces a symptomatic phenotype in transgenic tobacco plants. Proc. Natl. Acad. Sci. U.S.A. 85:733-737.

Benitez-Alfonso, Y., Faulkner, C., Ritzenthaler, C., and Maule, A. J. 2010. Plasmodesmata: Gateways to local and systemic virus infection. Mol. Plant-Microbe Interact. 23:1403-1412.

Blackman, L. M., and Overall, R. L. 1998. Immunolocalization of the cytoskeleton to plasmodesmata of Chara corallina. Plant J. 14:733-741.

Blanc, S., Schmidt, I., Vantard, M., Scholthof, H. B., Kuhl, G., Esperandieu, P., Cerutti, M., and Louis, C. 1996. The aphid transmission factor of cauliflower mosaic virus forms a stable complex with microtubules in both insect and plant cells. Proc. Natl. Acad. Sci. U.S.A. 93:15158-15163.

Boevink, P., and Oparka, K. J. 2005. Virus-host interactions during movement processes. Plant Physiol. 138:1815-1821.

Boyko, V., Ferralli, J., and Heinlein, M. 2000. Cell-to-cell movement of TMV RNA is temperature-dependent and corresponds to the association of movement protein with microtubules. Plant J. 22:315-325.

Boyko, V., Hu, Q., Seemanpillai, M., Ashby, J., and Heinlein, M. 2007. Validation of microtubule-associated Tobacco mosaic virus RNA movement and involvement of microtubule-aligned particle trafficking. Plant J. 51:589-603.

Brandner, K., Sambade, A., Boutant, E., Didier, P., Mely, Y., Ritzenthaler, C., and Heinlein, M. 2008. Tobacco mosaic virus movement protein interacts with green fluorescent protein-tagged microtubule end-binding protein 1. Plant Physiol. 147:611-623.

Burckhardt, C. J., and Greber, U. F. 2009. Virus movements on the plasma membrane support infection and transmission between cells. PloS Pathog. 5:e1000621. Published online.

Cai, G., Romagnoli, S., Moscatelli, A., Ovidi, E., Gambellini, G., Tiezzi, A., and Cresti, M. 2000. Identification and characterization of a novel microtubule-based motor associated with membranous organelles in tobacco pollen tubes. Plant Cell 12:1719-1736.

Canto, T., and Palukaitis, P. 2005. Subcellular distribution of mutant movement proteins of Cucumber mosaic virus fused to green fluorescent proteins. J. Gen. Virol. 86:1223-1228.

Carette, J. E., Stuiver, M., Van Lent, J., Wellink, J., and Van Kammen, A. B. 2000. Cowpea mosaic virus infection induces a massive proliferation of endoplasmic reticulum but not Golgi membranes and is dependent on de novo membrane synthesis. J. Virol. 74:6556-6563.

Carette, J. E., Verver, J., Martens, J., van Kampen, T., Wellink, J., and Van Kammen, A. B. 2002. Characterization of plant proteins that interact with Cowpea mosaic virus ' $60 \mathrm{~K}$ ' protein in the yeast two-hybrid system. J. Gen. Virol. 83:885-893.

Christensen, N., Tilsner, J., Bell, K., Hammann, P., Parton, R., Lacomme, C., and Oparka, K. 2009. The 5' cap of Tobacco mosaic virus (TMV) is required for virion attachment to the actin/endoplasmic reticulum network during early infection. Traffic 10:536-551.

Cillo, F., Roberts, I. M., and Palukaitis, P. 2002. In situ localization and tissue distribution of the replication-associated proteins of Cucumber mosaic virus in tobacco and cucumber. J. Virol. 76:10654-10664.

Cotton, S., Grangeon, R., Thivierge, K., Mathieu, I., Ide, C., Wei, T., Wang, A., and Laliberte, J. F. 2009. Turnip mosaic virus RNA replication complex vesicles are mobile, align with microfilaments, and are each derived from a single viral genome. J. Virol. 83:799-809. 
Cowan, G. H., Lioliopoulou, F., Ziegler, A., and Torrance, L. 2002. Subcellular localization, protein interactions, and RNA binding of potato mop-top virus triple gene block proteins. Virology 298:106-115.

Cui, X., Wei, T., Chowda-Reddy, R. V., Sun, G., and Wang, A. 2010. The Tobacco etch virus $\mathrm{P} 3$ protein forms mobile inclusions via the early secretory pathway and traffics along actin microfilaments. Virology 397:56-63.

Curin, M., Ojangu, E. L., Trutnyeva, K., Ilau, B., Truve, E., and Waigmann, E. 2007. MPB2C, a microtubule-associated plant factor, is required for microtubular accumulation of Tobacco mosaic virus movement protein in plants. Plant Physiol. 143:801-811.

Derrick, P. M., Barker, H., and Oparka, K. J. 1992. Increase in plasmodesmatal permeability during cell-to-cell spread of tobacco rattle virus from individually inoculated cells. Plant Cell 4:1405-1412.

Ding, B., Kwon, M. O., and Warnberg, L. 1996. Evidence that actin filaments are involved in controlling the permeability of plasmodesmata in tobacco mesophyll. Plant J. 10:157-164.

Ding, X. S., Liu, J., Cheng, N. H., Folimonov, A., Hou, Y. M., Bao, Y., Katagi, C., Carter, S. A., and Nelson, R. S. 2004. The Tobacco mosaic virus $126-\mathrm{kDa}$ protein associated with virus replication and movement suppresses RNA silencing. Mol. Plant-Microbe Interact. 17:583-592.

dos Reis Figueira, A., Golem, S., Goregaoker, S. P., and Culver, J. N. 2002. A nuclear localization signal and a membrane association domain contribute to the cellular localization of the Tobacco mosaic virus 126$\mathrm{kDa}$ replicase protein. Virology 301:81-89.

Ellgaard, L., and Helenius, A. 2003. Quality control in the endoplasmic reticulum. Nat. Rev. Mol. Cell Biol. 4:181-191.

Epel, B. L. 2009. Plant viruses spread by diffusion on ER-associated movement-protein-rafts through plasmodesmata gated by viral induced host $\beta$-1,3-glucanases. Semin. Cell Dev. Biol. 20:1074-1081.

Erhardt, M., Vetter, G., Gilmer, D., Bouzoubaa, S., Richards, K., Jonard, G., and Guilley, H. 2005. Subcellular localization of the triple gene block movement proteins of Beet necrotic yellow vein virus by electron microscopy. Virology 340:155-166.

Faulkner, C. R., Blackman, L. M., Collings, D. A., Cordwell, S. J., and Overall, R. L. 2009. Anti-tropomyosin antibodies co-localise with actin microfilaments and label plasmodesmata. Eur. J. Cell Biol. 88:357-369

Ferralli J., Ashby, J., Fasler, M., Boyko, V., and Heinlein, M. 2006. Disruption of microtubule organization and centrosome function by expression of Tobacco mosaic virus movement protein. J. Virol. 80:5807-5821

Forest, T., Barnard, S., and Baines, J. D. 2005. Active intranuclear movement of herpesvirus capsids. Nat. Cell Biol. 7:429-431.

Frischmuth, S., Wege, C., Hülser, D., and Jeske, H. 2007. The movement protein $\mathrm{BC} 1$ promotes redirection of the nuclear shuttle protein $\mathrm{BV} 1$ of Abutilon mosaic geminivirus to the plasma membrane in fission yeast. Protoplasma 230:117-123.

Fry, P. R., and Matthews, R. E. F. 1963. Timing of some early events following inoculation with tobacco mosaic virus. Virology 19:461-469.

Fujiki, M., Kawakami, S., Kim, R. W., and Beachy, R. N. 2006. Domains of Tobacco mosaic virus movement protein essential for its membrane association. J. Gen. Virol. 87:2699-2707.

Gal-On, A, Kaplan, I., Roossinck, M. J., and Palukaitis, P. 1994. The kinetics of infection of zucchini squash by cucumber mosaic virus indicate a function for RNA 1 in virus movement. Virology 205:280-289.

Genovés, A., Navarro, J. A., and Pallás, V. 2010. The intra-and intercellular movement of Melon necrotic spot virus (MNSV) depends on an active secretory pathway. Mol. Plant-Microbe Interact. 23:263-272.

Gillespie, T., Boevink, P., Haupt, S., Roberts, A. G., Toth, R., Valentine, T., Chapman, S., and Oparka, K. J. 2002. Functional analysis of a DNAshuffled movement protein reveals that microtubules are dispensable for the cell-to-cell movement of Tobacco mosaic virus. Plant Cell 14:12071222.

Golomb, L., Abu-Abied, M., Belausov, E., and Sadot, E. 2008. Different subcellular localizations and functions of Arabidopsis myosin VIII. BMC Plant Biol. 8:3.

Goodin, M. M., Chakrabarty, R., Yelton, S., Martin, K., Clark, A., and Brooks, R. 2007. Membrane and protein dynamics in live plant nuclei infected with Sonchus yellow net virus, a plant-adapted rhabdovirus. J. Gen. Virol. 88:1810-1820.

Gopinath, K., Dragnea, B., and Kao, C. 2005. Interaction between Brome mosaic virus proteins and RNAs: Effects on RNA replication, protein expression, and RNA stability. J. Virol. 79:14222-14234.

Gorshkova, E. N., Erokhina, T. N., Stroganova, T. A., Yelina, N. E., Zamyatnin, A. A., Jr., Kalinina, N. O., Schiemann, J., Solovyev, A. G., and Morozov, S. Y. 2003. Immunodetection and fluorescent microscopy of transgenically expressed hordeivirus TGBp3 movement protein reveals its association with endoplasmic reticulum elements in close proximity to plasmodesmata. J. Gen. Virol. 84:985-994.

Greber, U. F., and Way, M. 2006. A superhighway to virus infection. Cell 124:741-754.
Guenoune-Gelbart, D., Elbaum, M., Sagi, G., Levy, A., and Epel, B. L. 2008. Tobacco mosaic virus (TMV) replicase and movement protein function synergistically in facilitating TMV spread by lateral diffusion in the plasmodesmal desmotubule of Nicotiana benthamiana. Mol. Plant-Microbe Interact. 21:335-345.

Haas, M., Geldreich, A., Bureau, M., Dupuis, L., Leh, V., Vetter, G., Kobayashi, K., Hohn, T., Ryabova, L., and Yot. P. 2005. The open reading frame VI product of Cauliflower mosaic virus is a nucleocytoplasmic protein: Its $\mathrm{N}$ terminus mediates its nuclear export and formation of electron-dense viroplasms. Plant Cell 17:927-943.

Hagiwara, Y., Komoda, K., Yamanaka, T., Tamai, A., Meshi, T., Funada, R., Tsuchiya, T., Naito, S., and Ishikawa, M. 2003. Subcellular localization of host and viral proteins associated with tobamovirus RNA replication. EMBO (Eur. Mol. Biol. Organ.) J. 22:344-353.

Hanton, S. L., Matheson, L. A., Chatre, L., Rossi, M., and Brandizzi, F. 2007. Post-Golgi protein traffic in the plant secretory pathway. Plant Cell Rep. 26:1431-1438.

Harries, P. A., and Nelson, R. S. 2008. Movement of viruses in plants. Pages 348-355 in: Encyclopedia of Virology. B. W. J. Mahy and M. H. V. Van Regenmortel, eds. Elsevier Ltd., Oxford.

Harries, P. A., Palanichelvam, K., Yu, W., Schoelz, J. E., and Nelson, R. S. 2009a. The Cauliflower mosaic virus protein P6 forms motile inclusions that traffic along actin microfilaments and stabilize microtubules. Plant Physiol. 149:1005-1016.

Harries, P. A., Park, J. W., Nobumitsu, S., Ballard, K. D., Maule, A. J., and Nelson, R. S. 2009b. Differing requirements for actin and myosin by plant viruses for intercellular movement. Proc. Natl. Acad. Sci. U.S.A. 106:17594-17599.

Haupt, S., Cowan, G. H., Ziegler, A., Roberts, A. G., Oparka, K. J., and Torrance, L. 2005. Two plant-viral movement proteins traffic in the endocytic recycling pathway. Plant Cell 17:164-181.

Heinlein, M., Epel, B. L., Padgett, H. S., and Beachy, R. N. 1995. Interaction of tobamovirus movement proteins with the plant cytoskeleton. Science 270:1983-1985.

Heinlein, M., Padgett, H. S., Gens, J. S., Pickard, B. G., Casper, S. J., Epel, B. L., and Beachy, R. N. 1998. Changing patterns of localization of the tobacco mosaic virus movement protein and replicase to the endoplasmic reticulum and microtubules during infection. Plant Cell 10:1107-1120.

Hirashima, K., and Watanabe, Y. 2001. Tobamovirus replicase coding region is involved in cell-to-cell movement. J. Virol. 75:8831-8836.

Hirashima, K. and Watanabej, Y. 2003. RNA helicase domain of tobamovirus replicase executes cell-to-cell movement possibly through collaboration with its nonconserved region. J. Virol. 77:12357-12362.

Hofmann, C., Sambade, A., and Heinlein, M. 2007. Plasmodesmata and intercellular transport of viral RNA. Biochem. Soc. Trans. 35:142-145.

Hofmann, C., Niehl, A., Sambade, A., Steinmetz, A., and Heinlein, M. 2009. Inhibition of Tobacco mosaic virus movement by expression of an actin-binding protein. Plant Physiol. 149:1810-1823.

Hsu, H. T., Chou, Y. L., Tseng, Y. H., Lin, Y. H., Lin, T. M., Lin, N. S., Hsu, Y. H., and Chang, B. Y. 2008. Topological properties of the triple gene block protein 2 of Bamboo mosaic virus. Virology 379:1-9.

Huang, M., and Zhang, L. 1999. Association of the movement protein of Alfalfa mosaic virus with the endoplasmic reticulum and its trafficking in epidermal cells of onion bulb scales. Mol. Plant-Microbe Interact. 12:680-690.

Huang, Z., Han, Y., and Howell, S. H. 2000. Formation of surface tubules and fluorescent foci in Arabidopsis thaliana protoplasts expressing a fusion between the green fluorescent protein and the Cauliflower mosaic virus movement protein. Virology 271:58-64.

Hussey, P. J., Ketelaar, T., and Deeks, M. J. 2006. Control of the actin cytoskeleton in plant cell growth. Annu. Rev. Plant Biol. 57:109-125.

Hwang, Y. T., McCartney, A. W., Gidda, S. K., and Mullen, R. T. 2008. Localization of the Carnation Italian ringspot virus replication protein p36 to the mitochondrial outer membrane is mediated by an internal targeting signal and the TOM complex. BMC Cell Biol. 9:126.

Jackson, A. O., Lim, H. S., Bragg, J., Ganesan, U., and Lee, M. Y. 2009. Hordeivirus replication, movement, and pathogenesis. Annu. Rev. Phytopathol. 47:385-422.

Ju, H. J., Samuels, T. D., Wang, Y. S., Blancaflor, E., Payton, M., Mitra, R., Krishnamurthy, K., Nelson, R. S., and Verchot-Lubicz, J. 2005. The Potato virus $X$ TGBp2 movement protein associates with endoplasmic reticulum-derived vesicles during virus infection. Plant Physiol. 138:1877-1895.

Ju, H. J., Brown, J. E., Ye, C. M., and Verchot-Lubicz, J. 2007. Mutations in the central domain of Potato virus $X$ TGBp2 eliminate granular vesicles and virus cell-to-cell trafficking J. Virol. 81:1899-1911.

Kaido, M., Tsuno, Y., Mise, K., and Okuno, T. 2009. Endoplasmic reticulum targeting of the Red clover necrotic mosaic virus movement protein 
is associated with the replication of viral RNA1 but not that of RNA2 Virology 395:232-242.

Karasev, A. V., Kashina, A. S., Gelfand, V. I., and Dolja, V. V. 1992. HSP70related $65 \mathrm{kDa}$ protein of beet yellows closterovirus is a microtubulebinding protein. FEBS (Fed. Eur. Biochem. Soc.) Lett. 304:12-14.

Kawakami, S., Watanabe, Y., and Beachy, R. N. 2004. Tobacco mosaic virus infection spreads cell to cell as intact replication complexes. Proc. Natl. Acad. Sci. U.S.A.101:6291-6296.

Kragler, F., Curin, M., Trutnyeva, K., Gansch, A., and Waigmann, E. 2003. MPB2C, a microtubule-associated plant protein binds to and interferes with cell-to-cell transport of Tobacco mosaic virus movement protein. Plant Physiol. 132:1870-1883.

Krishnamurthy, K., Heppler, M., Mitra, R., Blancaflor, E., Payton, M., Nelson, R. S., and Verchot-Lubicz, J. 2003. The Potato virus X TGBp3 protein associates with the ER network for virus cell-to-cell movement. Virology 309:135-151.

Lanzetti, L. 2007. Actin in membrane trafficking. Curr. Opin. Cell Biol. 19:453-458.

Laporte, C., Vetter, G., Loudes, A. M., Robinson, D. G., Hillmer, S., Stussi-Garaud, C., and Ritzenthaler, C. 2003. Involvement of the secretory pathway and the cytoskeleton in intracellular targeting and tubule assembly of Grapevine fanleaf virus movement protein in tobacco BY-2 cells. Plant Cell 15:2058-2075.

Lee, Y. R. J., and Liu, B. 2004. Cytoskeletal motors in Arabidopsis. Sixtyone kinesins and seventeen myosins. Plant Physiol. 136:3877-3883.

Lewis, J. D., and Lazarowitz, S. G. 2010. Arabidopsis synaptotagmin SYTA regulates endocytosis and virus movement protein cell-to-cell transport. Proc. Natl. Acad. Sci. U.S.A. 107:2491-2496.

Li, J.-F., and Nebenfuhr, A. 2007. The tail that wags the dog: The globular tail domain defines the function of myosin V/XI. Traffic 9:290-298.

Lim, H. S., Bragg, J. N., Ganesan, U., Ruzin, S., Schichnes, D., Lee, M. Y., Vaira, A. M., Ryu, K. H., Hammond, J., and Jackson, A. O. 2009. Subcellular localization of the Barley stripe mosaic virus triple gene block proteins. J. Virol. 83:9432-9448.

Lipka, V., Kwon, C., and Panstruga, R. 2007. SNARE-ware: The role of SNARE-domain proteins in plant biology. Annu. Rev. Cell Dev. Biol. 23:147-174.

Lippincott-Schwartz, J., Snapp, E., and Kenworthy, A. 2001. Studying protein dynamics in living cells. Nat. Rev. Mol. Cell Biol. 2:444-456.

Liu, C., Meng, C., Xie, L., Hong, J., and Zhou, X. 2009. Cell-to-cell trafficking, subcellular distribution, and binding to coat protein of Broad bean wilt virus 2 VP37 protein. Virus Res. 143:86-93.

Liu, J. Z., Blancaflor, E. B., and Nelson, R. S. 2005. The Tobacco mosaic virus 126-kilodalton protein, a constituent of the virus replication complex, alone or within the complex aligns with and traffics along microfilaments. Plant Physiol. 138:1853-1865.

Liu, L., Westler, W. M., Den Boon, J. A., Wang, X., Diaz, A., Steinberg, H. A., and Ahlquist, P. 2009. An amphipathic -helix controls multiple roles of Brome mosaic virus protein 1a in RNA replication complex assembly and function. PLoS Pathog. 5:e1000351. Published online.

Love, A. J., Laird, J., Holt, J., Hamilton, A. J., Sadanandom, A., and Milner, J. J. 2007. Cauliflower mosaic virus protein P6 is a suppressor of RNA silencing. J. Gen. Virol. 88:3439-3444.

Lucas, W. J., Ham, B.-K., and Kim, J.-Y. 2009. Plasmodesmata-bridging the gap between neighboring plant cells. Trends Cell Biol. 19:495-503.

Marsh, M., and Helenius, A. 2006. Virus entry: Open sesame. Cell 124:729-740

Martínez-Gil, L., Saurí, A., Vilar, M., Pallás, V., and Mingarro, I. 2007. Membrane insertion and topology of the p7B movement protein of Melon necrotic spot virus (MNSV). Virology 367:348-357.

Martínez-Gil, L., Sánchez-Navarro, J. A., Cruz, A., Pallás, V., Pérez-Gil, J., and Mingarro, I. 2009. Plant virus cell-to-cell movement is not dependent on the transmembrane disposition of its movement protein. J. Virol. 83:5535-5543.

Martínez-Gil, L., Johnson, A. E., and Mingarro, I. 2010. Membrane insertion and biogenesis of the Turnip crinkle virus $\mathrm{p} 9$ movement protein. J. Virol. 84:348-357.

Martinière, A., Gargani, D., Uzest, M., Lautredou, N., Blanc, S., and Drucker, M. 2009. A role for plant microtubules in the formation of transmission-specific inclusion bodies of Cauliflower mosaic virus. Plant J. 58:135-146.

Más, P., and Beachy, R. N. 1999. Replication of tobacco mosaic virus on endoplasmic reticulum and role of the cytoskeleton and virus movement protein in intracellular distribution of viral RNA. J. Cell Biol. 147:945958.

Maule, A. J. 2008. Plasmodesmata: Structure, function and biogenesis. Curr. Opin. Plant Biol. 11:680-686.

McCartney, A. W., Greenwood, J. S., Fabian, M. R., White, K. A., and Mullen, R. T. 2005. Localization of the Tomato bushy stunt virus replication protein p33 reveals a peroxisome-to-endoplasmic reticulum sort- ing pathway. Plant Cell 17:3513-3531.

McLean, B. G., Zupan, J., and Zambryski, P. C. 1995. Tobacco mosaic virus movement protein associates with the cytoskeleton in tobacco cells. Plant Cell 7:2101-2114.

Medina, V., Peremyslov, V. V., Hagiwara, Y., and Dolja, V. V. 1999. Subcellular localization of the HSP70-homolog encoded by beet yellows closterovirus. Virology 260:173-181.

Mitra, R., Krishnamurthy, K., Blancaflor, E., Payton, M., Nelson, R. S., and Verchot-Lubicz, J. 2003. The Potato virus X TGBp2 protein association with the endoplasmic reticulum plays a role in but is not sufficient for viral cell-to-cell movement. Virology 312:35-48.

Moreau, P., Brandizzi, F., Hanton, S., Chatre, L., Melser, S., Hawes, C., and Satiat-Jeunemaitre, B. 2007. The plant ER-Golgi interface: A highly structured and dynamic membrane complex. J. Exp. Bot. 58:49-64.

Murphy, A. S., Bandyopadhyay, A., Holstein, S. E., and Peer, W. A. 2005. Endocytotic cycling of PM proteins. Annu. Rev. Plant Biol. 56:221251.

Nebenführ, A., Gallagher, L. A., Dunahay, T. G., Frohlick, J. A., Mazurkiewicz, A. M., Meehl, J. B., and Staehelin, L. A. 1999. Stopand-go movements of plant Golgi stacks are mediated by the acto-myosin system. Plant Physiol. 121:1127-1141.

Netherton, C., Moffat, K., Brooks, E., and Wileman, T. 2007. A guide to viral inclusions, membrane rearrangements, factories, and viroplasm produced during virus replication. Adv. Virus Res. 70:101-182.

Nishikiori, M., Dohi, K., Mori, M., Meshi, T., Naito, S., and Ishikawa, M. 2006. Membrane-bound Tomato mosaic virus replication proteins participate in RNA synthesis and are associated with host proteins in a pattern distinct from those that are not membrane bound. J. Virol. 80:84598468

Ouko, M. O., Sambade, A., Brandner, K., Niehl, A., Peña, E., Ahad, A., Heinlein, M., and Nick, P. 2010. Tobacco mutants with reduced microtubule dynamics are less susceptible to TMV. Plant J. 62:829-839.

Overall, R., and Blackman, L. 1996. A model of the macromolecular structure of plasmodesmata. Trends Plant Sci. 1:307-311.

Overall, R., White, R. G., Blackman, L. M., and Radford, J. E. 2000. Actin and myosin in plasmodesmata. Pages 497-515 in: Actin: Dynamic Framework for Multiple Plant Cell Functions. C. J. Staiger, ed. Kluwer Academic Publishers, Dordrecht, The Netherlands.

Padgett, H. S., Epel, B. L., Kahn, T. W., Heinlein, M., Watanabe, Y., and Beachy, R. N. 1996. Distribution of tobamovirus movement protein in infected cells and implications for cell-to-cell spread of infection. Plant J. 10:1079-1088.

Peremyslov, V. V., Hagiwara, Y., and Dolja, V. V. 1999. HSP70 homolog functions in cell-to-cell movement of a plant virus. Pro. Natl. Acad. Sci. U.S.A. 96:14771-14776.

Peremyslov, V. V., Pan, Y. W., and Dolja, V. V. 2004. Movement protein of a closterovirus is a type III integral transmembrane protein localized to the endoplasmic reticulum. J. Virol. 78:3704-3709.

Pierini, R., Cottam, E., Roberts, R., and Wileman, T. 2009. Modulation of membrane traffic between endoplasmic reticulum, ERGIC and Golgi to generate compartments for the replication of bacteria and viruses. Semin. Cell Dev. Biol. 20:828-833.

Pollard, T. D., and Cooper, J. A. 2009. Actin, a central player in cell shape and movement. Science 326:1208-1212

Pouwels, J., Van Der Krogt, G. N. M., Van Lent, J., Bisseling, T., and Wellink, J. 2002. The cytoskeleton and the secretory pathway are not involved in targeting the cowpea mosaic virus movement protein to the cell periphery. Virology 297:48-56.

Prokhnevsky, A. I., Peremyslov, V. V., and Dolja, V. V. 2005. Actin cytoskeleton is involved in targeting of a viral Hsp70 homolog to the cell periphery. J. Virol. 79:14421-14428.

Prokhnevsky, A. I., Permyslov, V. V., and Dolja, V. V. 2008. Overlapping functions of the four class XI myosins in Arabidopsis growth, root hair elongation, and organelle motility. Proc. Natl. Acad. Sci. U.S.A. 105:19744-19749

Qi, D., Omarov, R. T., and Scholthof, K. B. 2008. The complex subcellular distribution of satellite Panicum mosaic virus capsid protein reflects its multifunctional role during infection. Virology 376:154-164.

Radtke, K., Döhner, K., and Sodeik, B. 2006. Viral interactions with the cytoskeleton: A hitchhiker's guide to the cell. Cell Microbiol. 8:387400.

Raffaele, S., Bayer, E., Lafarge, D., Cluzet, S., German Retana, S., Boubekeur, T., Leborgne-Castel, N., Carde, J. P., Lherminier, J., and Noirot, E. 2009. Remorin, a Solanaceae protein resident in membrane rafts and plasmodesmata, impairs Potato virus $X$ movement. Plant Cell 21:1541-1555.

Rebelo, A. R., Niewiadomski, S., Prosser, S. W., Krell, P., and Meng, B. 2008. Subcellular localization of the triple gene block proteins encoded by a foveavirus infecting grapevines. Virus Res. 138:57-69.

Reichel, C., and Beachy, R. N. 1998. Tobacco mosaic virus infection in- 
duces severe morphological changes of the endoplasmic reticulum. Proc. Natl. Acad. Sci. U.S.A. 95:11169-11174.

Reichelt, S., Knight, A. E., Hodge, T. P., Baluska, F., Samaj, J., Volkmann, D., and Kendrick-Jones, J. 1999. Characterization of the unconventional myosin VIII in plant cells and its localization at the post-cytokinetic cell wall. Plant J. 19:555-567.

Restrepo-Hartwig, M. A., and Ahlquist, P. 1996. Brome mosaic virus helicase-and polymerase-like proteins colocalize on the endoplasmic reticulum at sites of viral RNA synthesis. J. Virol. 70:8908-8916.

Ribeiro, D., Foresti, O., Denecke, J., Wellink, J., Goldbach, R., and Kormelink, R. J. M. 2008. Tomato spotted wilt virus glycoproteins induce the formation of endoplasmic reticulum-and Golgi-derived pleomorphic membrane structures in plant cells. J. Gen. Virol. 89:1811-1818.

Ribeiro, D., Goldbach, R., and Kormelink, R. 2009. Requirements for ERarrest and sequential exit to the Golgi of Tomato spotted wilt virus glycoproteins. Traffic 10:664-672.

Ritzenthaler, C., Laporte, C., Gaire, F., Dunoyer, P., Schmitt, C., Duval, S., Piéquet, A., Loudes, A. M., Rohfritsch, O., Stussi-Garaud, C., and Pfeiffer, P. 2002. Grapevine fanleaf virus replication occurs on endoplasmic-reticulum-derived membranes. J. Virol. 76:8808-8819.

Ruggenthaler, P., Fichtenbauer, D., Krasensky, J., Jonak, C., and Waigmann, E. 2009. Microtubule-associated protein AtMPB2C plays a role in organization of cortical microtubules, stomata patterning, and tobamovirus infectivity. Plant Physiol. 149:1354-1365.

Ryabova, L. A., Pooggin, M. M., and Hohn, T. 2002. Viral strategies of translation initiation: Ribosomal shunt and reinitiation. Prog. Nucleic Acid Res. Mol. Biol. 272:1-39.

Sambade, A., Brandner, K., Hofmann, C., Seemanpillai, M., Mutterer, J., and Heinlein, M. 2008. Transport of TMV movement protein particles associated with the targeting of RNA to plasmodesmata. Traffic 9:2073-2088.

Sanfaçon, H. 2005. Replication of positive-strand RNA viruses in plants: Contact points between plant and virus components. Can. J. Bot. 83:1529-1549.

Sasaki, H., Nakamura, M., Ohno, T., Matsuda, Y., Yuda, Y., and Nonomura Y. 1995. Myosin-actin interaction plays an important role in human immunodeficiency virus type 1 release from host cells. Proc. Natl. Acad. Sci. U.S.A. 92:2026-2030.

Schepetilnikov, M. V., Manske, U., Solovyev, A. G., Zamyatnin, A. A., Jr., Schiemann, J., and Morozov, S. Y. 2005. The hydrophobic segment of Potato virus $X$ TGBp3 is a major determinant of the protein intracellular trafficking. J. Gen. Virol. 86:2379-2391.

Schepetilnikov, M. V., Solovyev, A. G., Gorshkova, E. N., Schiemann, J., Prokhnevsky, A. I., Dolja, V. V., and Morozov, S. Y. 2008. Intracellular targeting of a hordeiviral membrane-spanning movement protein: Sequence requirements and involvement of an unconventional mechanism. J. Virol. 82:1284-1293.

Schoelz, J., Shepherd, R. J., and Daubert, S. 1986. Region VI of cauliflower mosaic virus encodes a host range determinant. Mol. Cell Biol. 6:2632-2637.

Scholthof, H. B. 2005. Plant virus transport: Motions of functional equivalence. Trends Plant Sci. 10:376-382

Seemanpillai, M., Elamawi, R., Ritzenthaler, C., and Heinlein, M. 2006. Challenging the role of microtubules in Tobacco mosaic virus movement by drug treatments is disputable. J. Virol. 80:5807-5821.

Serazev, T. V., Nadezhdina, E. S., Shanina, N. A., Leshchiner, A. D., Kalinina, N. O., and Morozov, S. I. 2003. Virions and membrane proteins of the potato $\mathrm{X}$ virus interact with microtubules and enables tubulin polymerization in vitro. Mol. Biol. 37:919-925.

Serva, S., and Nagy, P. D. 2006. Proteomics analysis of the tombusvirus replicase: Hsp70 molecular chaperone is associated with the replicase and enhances viral RNA replication. J. Virol. 80:2162-2169.

Shimizu, T., Yoshii, A., Sakurai, K., Hamada, K., Yamaji, Y., Suzuki, M., Namba, S., and Hibi, T. 2009. Identification of a novel tobacco DnaJlike protein that interacts with the movement protein of Tobacco mosaic virus. Arch. Virol. 154:959-967

Solovyev, A. G., Stroganova, T. A., Zamyatnin, A. A., Fedorkin, O. N., Schiemann, J., and Yu Morozov, S. 2000. Subcellular sorting of small membrane-associated triple gene block proteins: TGBp3-assisted targeting of TGBp2. Virology 269:113-127.

Sparkes, I., Runions, J., Hawes, C., and Griffing, L. 2009. Movement and remodeling of the endoplasmic reticulum in nondividing cells of tobacco leaves. Plant Cell 21:3937-3949.

Su, S., Liu, Z., Chen, C., Zhang, Y., Wang, X., Zhu, L., Miao, L., Wang, X. C., and Yuan, M. 2010. Cucumber mosaic virus movement protein severs actin filaments to increase the plasmodesmal size exclusion limit in tobacco. Plant Cell 22:1373-1387.
Tagami, Y., and Watanabe, Y. 2007. Effects of brefeldin A on the localization of tobamovirus movement protein and cell-to-cell movement of the virus. Virology 361:133-140.

Tilsner, J., Cowan, G. H., Roberts, A. G., Chapman, S. N., Ziegler, A., Savenkov, E., and Torrance, L. 2010. Plasmodesmal targeting and intercellular movement of Potato mop-top pomovirus is mediated by a membrane anchored tyrosine-based motif on the lumenal side of the endoplasmic reticulum and the $\mathrm{C}$-terminal transmembrane domain in the TGB3 movement protein. Virology 402:41-51.

Torrance, L., Cowan, G. H., Gillespie, T., Ziegler, A., and Lacomme, C. 2006. Barley stripe mosaic virus-encoded proteins triple-gene block 2 and $\gamma \mathrm{b}$ localize to chloroplasts in virus-infected monocot and dicot plants, revealing hitherto-unknown roles in virus replication. J. Gen. Virol. 87:2403-24011.

Tyulkina, L. G., Karger, E. M., Sheveleva, A. A., and Atabekov, J. G. 2010. Binding of monoclonal antibodies to movement protein (MP) of Tobacco mosaic virus: Influence of subcellular MP localization and phosphorylation. J. Gen. Virol. 91:1621-1628.

Van Der Heijden, M. W., Carette, J. E., Reinhoud, P. J., Haegi, A., and Bol, J. F. 2001. Alfalfa mosaic virus replicase proteins P1 and P2 interact and colocalize at the vacuolar membrane. J. Virol. 75:1879-1887.

Verchot-Lubicz, J., Ye, C. M., and Bamunusinghe, D. 2007. Molecular biology of potexviruses: Recent advances. J. Gen. Virol. 88:1643-1655.

Vilar, M., Sauri, A., Monne, M., Marcos, J. F., von Heijne, G., Perez-Paya, E., and Mingarro, I. 2002. Insertion and topology of a plant viral movement protein in the endoplasmic reticulum membrane. J. Biol. Chem. 277:23447-23452.

Vogel, F., Hofius, D., and Sonnewald, U. 2007. Intracellular trafficking of Potato leafroll virus movement protein in transgenic Arabidopsis. Traffic 8:1205-1214.

von Bargen, S., Salchert, K., Paape, M., Piechulla, B., and Kellmann, J. W. 2001. Interactions between the Tomato spotted wilt virus movement protein and plant proteins showing homologies to myosin, kinesin and DnaJ-like chaperones. Plant Physiol. Biochem. 39:1083-1093.

Wada, M., and Suetsugu, N. 2004. Plant organelle positioning. Curr. Opin. Plant Biol. 7:626-631.

Waigmann, E., Ueki, S., Trutnyeva, K., and Citovsky, V. 2004. The ins and outs of nondestructive cell-to-cell and systemic movement of plant viruses. Crit. Rev. Plant Sci. 23:195-250.

Wang, R. Y. L., Stork, J., Pogany, J., and Nagy, P. D. 2009. A temperature sensitive mutant of heat shock protein 70 reveals an essential role during the early steps of tombusvirus replication. Virology 394:28-38.

Ward, B. M., Medville, R., Lazarowitz, S. G., and Turgeon, R. 1997. The geminivirus BL1 movement protein is associated with endoplasmic reticulum-derived tubules in developing phloem cells. J. Virol. 71:37263733

Wei, T., Kikuchi, A., Moriyasu, Y., Suzuki, N., Shimizu, T., Hagiwara, K., Chen, H., Takahashi, M., Ichiki-Uehara, T., and Omura, T. 2006. The spread of Rice dwarf virus among cells of its insect vector exploits virus-induced tubular structures. J. Virol. 80:8593-8602.

Wei, T., Shimizu, T., and Omura, T. 2008. Endomembranes and myosin mediate assembly into tubules of Pns10 of Rice dwarf virus and intercellular spreading of the virus in cultured insect vector cells. Virology 372:349-356.

Wei, T., Uehara-Ichiki, T., Miyazaki, N., Hibino, H., Iwasaki, K., and Omura, T. 2009. Association of Rice gall dwarf virus with microtubules is necessary for viral release from cultured insect vector cells. J. Virol. 83:10830-10835

Wei, T., Huang, T. S., McNeil, J., Laliberte, J. F., Hong, J., Nelson, R. S., and Wang, A. 2010. Sequential recruitment of the endoplasmic reticulum and chloroplasts for plant potyvirus replication. J. Virol. 84:799-809.

White, R. G., Badelt, K., Overall, R. L., and Vesk, M. 1994. Actin associated with plasmodesmata. Protoplasma 180:169-184.

Wright, K. M., Wood, N. T., Roberts, A. G., Chapman, S., Boevink, P., MacKenzie, K. M., and Oparka, K. J. 2007. Targeting of TMV movement protein to plasmodesmata requires the actin/ER network; evidence from FRAP. Traffic 8:21-31.

Yamanaka, T., Ohta, T., Takahashi, M., Meshi, T., Schmidt, R., Dean, C., Naito, S., and Ishikawa, M. 2000. TOM1, an Arabidopsis gene required for efficient multiplication of a tobamovirus, encodes a putative transmembrane protein. Proc. Natl. Acad. Sci. U.S.A. 97:10107-10112.

Zamyatnin, A. A., Jr., Solovyev, A. G., Sablina, A. A., Agranovsky, A. A. Katul, L., Vetten, H. J., Schiemann, J., Hinkkanen, A. E., Lehto, K., and Morozov, S. Y. 2002. Dual-colour imaging of membrane protein targeting directed by Poa semilatent virus movement protein TGBp3 in plant and mammalian cells. J. Gen. Virol. 83:651-662. 